\title{
Effect of temperature and type of packages on quality of stored lettuce
}

\author{
JÓZEF BĄKOWSKI, HELENA MICHALIK, MARCIN HORBOWICZ
}

\author{
Research Institute of Vegetable Crops, Department of Storage and Processing \\ Konstytucji 3 Maja 1/3, 96-100 Skierniewice, Poland
}

(Received: May 12, 1996)

\begin{abstract}
A bstract
Lettuce head cv. Sanora non-wrapped, wrapped with perforated PE film, unperforated PE film, and in stretch film was stored at different temperatures: $1,6,20$ and $28^{\circ} \mathrm{C}$. The lettuce can be stored at $1^{\circ} \mathrm{C}$ up to 10 days, and at $6^{\circ} \mathrm{C}$ during 8 days period. Longer storage time caused clear loses of lettuce quality. During first two - three days of storage in both temperatures 1 and $6^{\circ} \mathrm{C}$ loses of ascorbic acid, dry matter, colour and organoleptic value were not observed. Faster decrease of ascorbic acid content was noted in lettuce stored in unperforated PE film and stretch film, in comparison to perforated PE film. The highest lettuce quality were found in case where lettuce were stored in perforated PE bags at $1^{\circ} \mathrm{C}$.
\end{abstract}

\section{INTRODUCTION}

As a leafy vegetable, lettuce during storage quickly losses its freshness and colour. Polyethylene (PE) bags protect stored lettuce from loss of water and leaves senescence. Lettuce stored during five days at $5^{\circ} \mathrm{C}$ lost $45 \%$ of water in case of not packed, and up to $8 \%$ where lettuce was packed in PE bags (B o r o w s k i and $\mathrm{M} \mathrm{i} \mathrm{c} \mathrm{h} \mathrm{a} \mathrm{ł} \mathrm{e} \mathrm{k,} \mathrm{1994).} \mathrm{According} \mathrm{to} \mathrm{mentioned} \mathrm{authors} \mathrm{the} \mathrm{lettuce} \mathrm{stored} \mathrm{in} \mathrm{PE} \mathrm{bags}$ did not loss water, but respiratory processes cause decrease the oxygen and increase the carbon dioxide levels of the atmosphere inside bags. In such conditions anaerobes reduce nitrates to nitrites, and cause decreasing quality of lettuce.

M c D o n a l d et al. (1990) have studied effect of permeability for oxygen of PE films on the quality of stored lettuce. They have found that film more permeable to oxygen, during storage at temperature of $1^{\circ} \mathrm{C}$, better protect the lettuce quality in comparison to less permeable PE film. P o u l s e n et al. (1995) were noticed water 
and vitamin $\mathrm{C}$ loses during storage of lettuce. All the processes cause increase of metabolic fermentation and biosynthesis of ethanol and acetaldehyde inside the lettuce heads (M a t o e s et al., 1993).

According to $\mathrm{R} \mathrm{o} \dot{\mathrm{z}}$ e $\mathrm{k}$ et al. (1994) after one day of lettuce storage at 1 and $20^{\circ} \mathrm{C}$ level of vitamin $\mathrm{C}$ has increased, but in next days constantly decreased. A d a$\mathrm{m} \mathrm{i} \mathrm{c} \mathrm{k} \mathrm{i} \mathrm{(1989)} \mathrm{was} \mathrm{stated,} \mathrm{that} \mathrm{storage} \mathrm{condition} \mathrm{for} \mathrm{saving} \mathrm{the} \mathrm{highest} \mathrm{percentage}$ of vitamin $\mathrm{C}$ during storage of lettuce in temperature $1^{\circ} \mathrm{C}$ in modified atmosphere was the best.

\section{MATERIALS AND METHODS}

The experiments were performed with lettuce cv. Sanora. The lettuce was grown in greenhouse, and harvested in April and May, 1994. For the experiments only healthy and well looking heads were used. The following temperatures and films were used in the experiments: $1,6,20$ and $28^{\circ} \mathrm{C}$; unperforated PE film, perforated PE film, stretch film, in compare to storage of non-wrapped lettuce. The perforation of PE film was done by making 6 holes, $8 \mathrm{~mm}$ id. on area of about $1000 \mathrm{~cm}^{2}$. The width and length of each bag was $30 \mathrm{~cm}$ and $35 \mathrm{~cm}$ respectively. The lettuce was stored until loss of marketable quality. Evaluation of marketable value, ascorbic acid, dry matter and brightness levels were carried out every one or two days, depends on storage temperature. The marketable value was evaluated according to $\mathrm{K}$ a d e $\mathrm{r}$ et al. (1973) rating score. The ascorbic acid was determined using Tillmans titrimetric method, and dry matter was measured using gravimetric method by drying the chopped lettuce in laboratory fan dryer. The brightness $(\mathrm{L})$ was measured using ColorQuest apparatus (Hunter Associates Laboratory, Reston, Virginia, USA).

\section{RESULTS AND DISCUSSION}

Dry matter level in lettuce was depended on harvest time (table 1). The lettuce harvested in May had higher dry matter content than those harvested in April. Storage of the non-wrapped lettuce caused its much faster withering. Our results are agreed to data obtained by B o r o w s k i and M i c h a ł e k (1994). The storage in perforated PE film did not protect the lettuce against withering, but the losses of moisture were smaller. The increase of dry matter level in lettuce non-wrapped and wrapped in perforated $\mathrm{PE}$ film is smaller in low temperatures of storage $\left(1\right.$ and $\left.6^{\circ} \mathrm{C}\right)$ comparing to $20^{\circ} \mathrm{C}$. In the lettuce wrapped in unperforated PE film and stretch film storage did not cause significant changes of dry matter (table 1).

Level of the ascorbic acid was similar in lettuce harvested in April and May. During storage of lettuce in all temperatures and types of films used in the experiments the ascorbic acid decreased (Figures 1 and 2). During first two days of storage at 1 and $6^{\circ} \mathrm{C}$ of lettuce non-wrapped or wrapped in perforated PE film the ascorbic 
acid level did not change. After next two days decreases were relatively small, in comparison to quick decomposition of ascorbic acid in lettuce stored at 20 and $28^{\circ} \mathrm{C}$. Similar results were obtained by B ö t t c h e r (1988).

Larger loses of ascorbic acid were noted during storage at 1 and $6^{\circ} \mathrm{C}$ of lettuce wrapped in unperforated $\mathrm{PE}$ and stretch films, in comparison to lettuce wrapped in perforated PE bags and non-wrapped (Fig. 1). For high temperature of storage (20 and $28^{\circ} \mathrm{C}$ ), especially chosen to provoke changes of ascorbic acid, it has been found that lettuce stored in perforated PE bags contained higher amount of this vitamin then lettuce stored in other types of films (Fig. 2). Very quick losses of ascorbic acid in chopped lettuce placed in PE bags and stored at $5^{\circ} \mathrm{C}$ were noted by $\mathrm{He}$ i $\mathrm{m} \mathrm{d}$ a 1 et al. (1995). They have stated that lettuce should be store no longer than ten days to avoid lose of green colour and nutritional value. In our experiments after eight days storage at $6^{\circ} \mathrm{C}$, and after twelve days storage at $1^{\circ} \mathrm{C}$, we have visually observed loss of green colour, and increase of L (brightness) value (Fig. 3).

Table 1

Effect of storage conditions on dry matter level of lettuce (in \%)

\begin{tabular}{|c|c|c|c|c|c|c|c|c|c|}
\hline \multirow{2}{*}{$\begin{array}{c}\text { Storage } \\
\text { temp. } \\
\left({ }^{\circ} \mathrm{C}\right)\end{array}$} & \multirow{2}{*}{$\begin{array}{c}\text { Storage } \\
\text { time } \\
\text { (days) }\end{array}$} & \multicolumn{4}{|c|}{ Harvest time: April 6, 1994} & \multicolumn{4}{|c|}{ Harvest time: May 9, 1994} \\
\hline & & 1 & 2 & 3 & 4 & 1 & 2 & 3 & 4 \\
\hline \multicolumn{2}{|c|}{ Lettuce before storage } & \multicolumn{4}{|c|}{4.6} & \multicolumn{4}{|c|}{5.0} \\
\hline 1 & 2 & 4.6 & 4.4 & 4.4 & 4.6 & 5.0 & 4.8 & 4.9 & 4.9 \\
\hline 1 & 5 & 5.4 & 4.6 & 4.6 & 4.2 & 5.0 & 4.9 & 4.9 & 5.0 \\
\hline 1 & 7 & 5.6 & 4.6 & 4.7 & 4.8 & 5.6 & 4.8 & 4.8 & 5.1 \\
\hline 1 & 9 & 5.6 & 5.3 & 4.6 & 4.8 & 6.4 & 4.7 & 4.8 & 4.8 \\
\hline 1 & 12 & 5.6 & 5.4 & 4.7 & 4.2 & 6.2 & 4.8 & 4.9 & 4.5 \\
\hline 1 & 14 & 5.7 & 5.4 & 4.7 & 4.3 & 7.4 & 4.9 & 4.8 & 4.5 \\
\hline 1 & 16 & 6.0 & 5.5 & 4.4 & 4.3 & 7.0 & 5.4 & 4.7 & 4.5 \\
\hline \multicolumn{2}{|c|}{ LSD $\alpha=005$} & 0.7 & 0.4 & ns & $\mathrm{ns}$ & 0.6 & ns & $\mathrm{ns}$ & 0.4 \\
\hline 6 & 2 & 4.6 & 4.8 & 4.2 & 4.6 & 5.2 & 5.1 & 4.9 & 4.8 \\
\hline 6 & 5 & 4.5 & 4.7 & 4.3 & 4.6 & 5.2 & 5.4 & 5.0 & 5.0 \\
\hline 6 & 7 & 4.8 & 5.2 & 4.6 & 4.8 & 5.5 & 5.4 & 4.9 & 5.1 \\
\hline 6 & 9 & 5.3 & 5.2 & 4.6 & 4.7 & 5.8 & 5.6 & 5.0 & 4.8 \\
\hline 6 & 12 & 5.8 & 5.3 & 4.7 & 4.6 & 6.2 & 5.5 & 5.1 & 4.8 \\
\hline \multicolumn{2}{|c|}{$\operatorname{LSD} \alpha=006$} & 0.6 & 0.4 & 0.4 & ns & 0.5 & 0.4 & ns & $\mathrm{ns}$ \\
\hline 20 & 1 & 4.3 & 4.5 & 4.6 & 4.6 & 5.3 & 5.0 & 5.0 & 5.0 \\
\hline 20 & 2 & 4.6 & 4.6 & 4.7 & 4.6 & 5.5 & 5.0 & 5.2 & 5.1 \\
\hline 20 & 3 & 4.8 & 4.6 & 4.6 & 4.3 & 5.7 & 5.2 & 5.6 & 5.3 \\
\hline 20 & 4 & 5.2 & 4.8 & 4.6 & 4.2 & 6.0 & 5.6 & 5.4 & 4.4 \\
\hline \multicolumn{2}{|c|}{ LSD $\alpha=006$} & 0.4 & ns & ns & 0.3 & 0.5 & 0.4 & 0.5 & 0.3 \\
\hline 28 & 1 & 5.3 & 4.9 & 4.4 & 4.3 & 5.0 & 5.0 & 5.4 & 4.5 \\
\hline 28 & 2 & 5.8 & 5.1 & 4.5 & 4.3 & 4.9 & 5.6 & 5.5 & 4.7 \\
\hline 28 & 3 & 6.3 & 5.4 & 4.5 & 4.6 & 6.3 & 6.3 & 5.1 & 4.6 \\
\hline LSD 0 & 005 & 0.5 & 0.6 & ns & ns & 0.4 & 0.5 & ns & $\mathrm{ns}$ \\
\hline
\end{tabular}

Explanations: 1 - non-wrapped, 2 - wrapped in perforated PE film, 3 - wrapped in unperforated PE film, 4 - wrapped in stretch film, ns - non significant difference. 

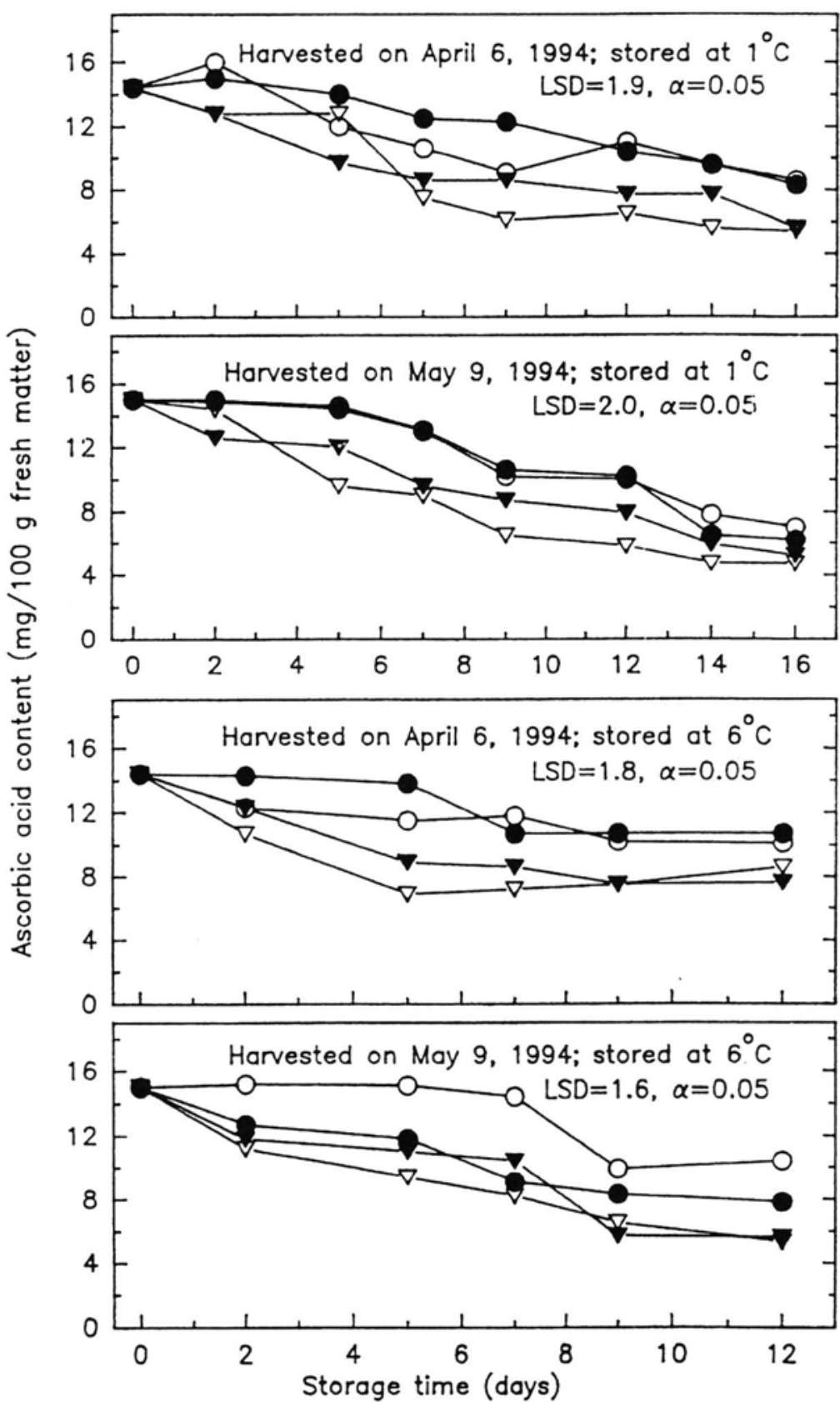

$O$ non-wrapped; - wrapped in perforated PE film $\nabla$ wrapped in unperforated PE film; $\nabla$ wrapped in stretch film 

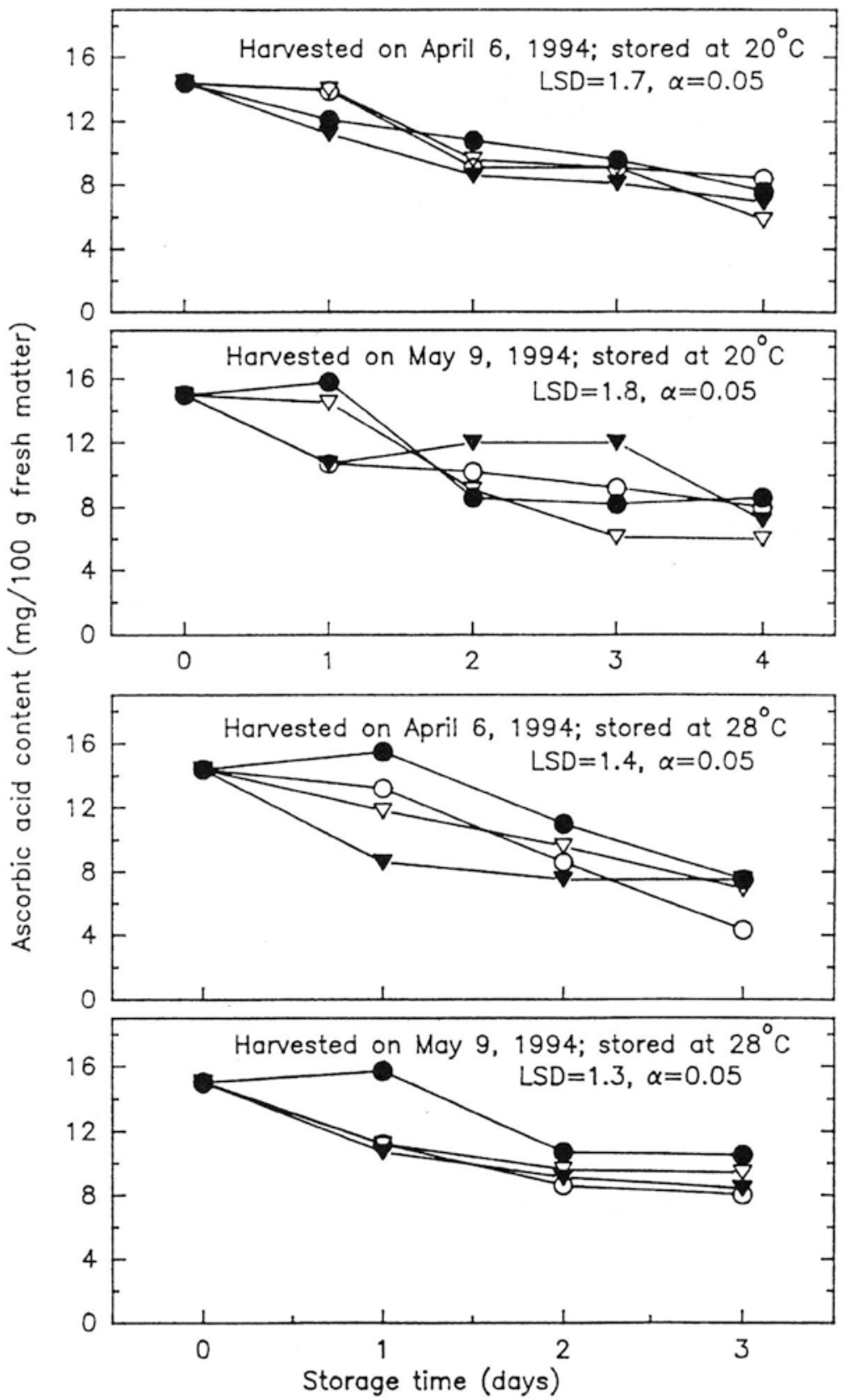

O non-wrapped; - wrapped in perforated PE film

$\nabla$ wrapped in unperforated PE film; $\boldsymbol{\nabla}$ wrapped in stretch film

Fig. 2. Changes of ascorbic acid content during storage of lettuce at temperature 20 and $28^{\circ} \mathrm{C}$ 


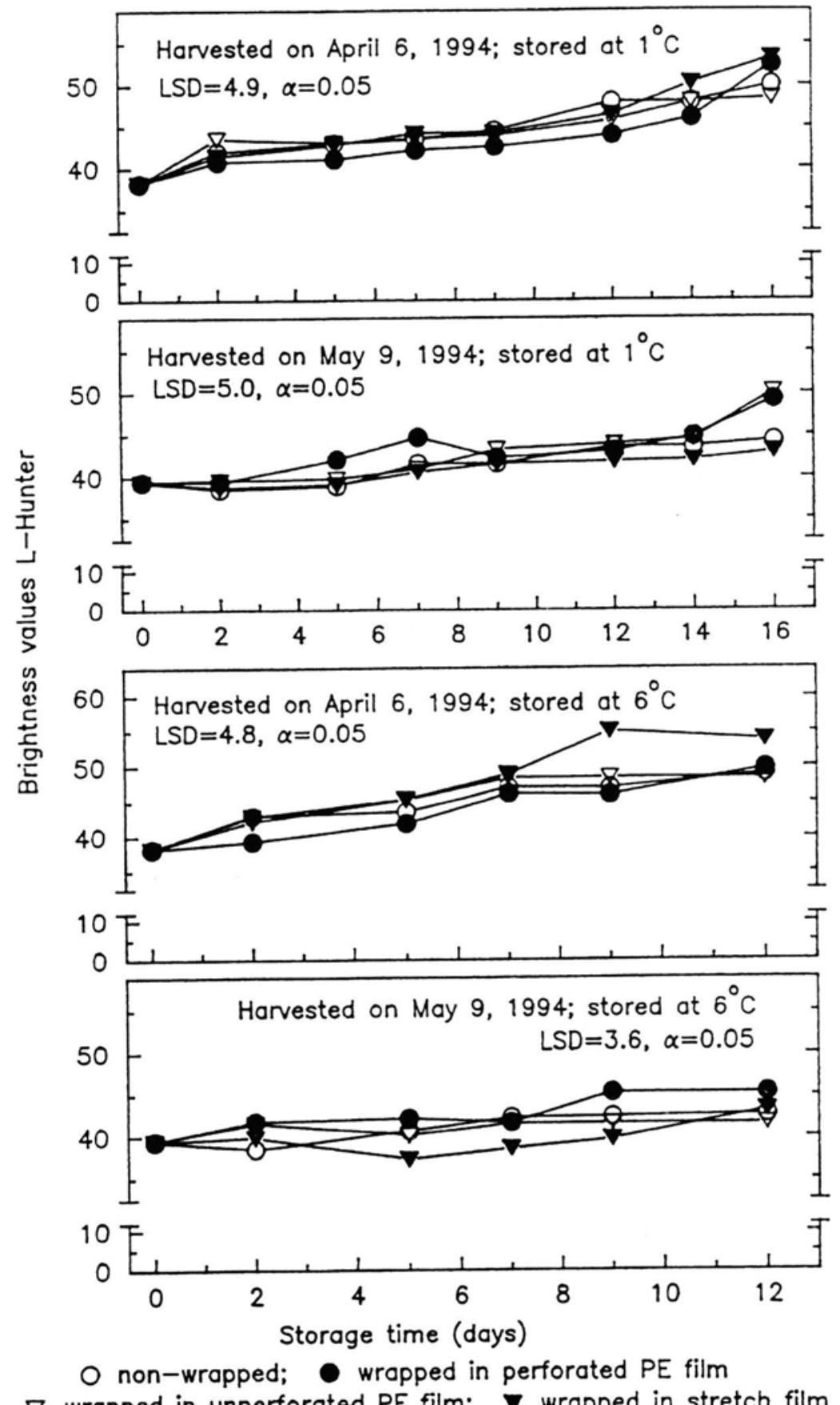

$\nabla$ wrapped in unperforated PE film; $\nabla$ wrapped in stretch film

Fig. 3. Changes of brightness value (L) of lettuce during storage at temperature 1 and $6^{\circ} \mathrm{C}$ 
The increase of $\mathrm{L}$ value was much faster during storage of lettuce at $20^{\circ} \mathrm{C}$, and has appeared after 2-3 days of storage. This changes was observed already after 24 hours in lettuce stored at $28^{\circ} \mathrm{C}$ (Fig. 4). After that time colour of lettuce was clearly poor, and the vegetable had no marketable value, because low organoleptic assessment (Table 2).

Film bags protect lettuce against losses of moisture, but during storage respiration processes change composition of inner atmosphere: lower the oxygen and increase carbon dioxide concentration. Quick changes of colour, smell and tissue decay were observed in lettuce stored in unperforated PE bags.

Table 2

Effect of storage conditions on organoleptic evaluation of lettuce

\begin{tabular}{|c|c|c|c|c|c|c|c|c|c|}
\hline \multirow{2}{*}{$\begin{array}{c}\text { Storage } \\
\text { temp. } \\
\left({ }^{\circ} \mathrm{C}\right)\end{array}$} & \multirow{2}{*}{$\begin{array}{l}\text { Storage } \\
\text { time } \\
\text { (days) }\end{array}$} & \multicolumn{4}{|c|}{ Harvest time: April 6, 1994} & \multicolumn{4}{|c|}{ Harvest time: May 9, 1994} \\
\hline & & 1 & 2 & 3 & 4 & 1 & 2 & 3 & 4 \\
\hline \multicolumn{2}{|c|}{ Lettuce before storage } & \multicolumn{4}{|c|}{9.0} & \multicolumn{4}{|c|}{8.5} \\
\hline 1 & 2 & 9.0 & 9.0 & 9.0 & 9.0 & 7.5 & 8.0 & 8.0 & 8.0 \\
\hline 1 & 5 & 7.0 & 9.0 & 9.0 & 9.0 & 7.0 & 8.0 & 8.0 & 8.0 \\
\hline 1 & 7 & 5.0 & 8.5 & 8.0 & 8.0 & 6.0 & 7.0 & 7.5 & 7.5 \\
\hline 1 & 9 & 4.0 & 8.0 & 6.0 & 6.0 & 5.0 & 6.0 & 7.0 & 6.0 \\
\hline 1 & 12 & 4.0 & 8.0 & 6.0 & 6.0 & 3.0 & 4.0 & 7.0 & 6.0 \\
\hline 1 & 14 & 4.0 & 8.0 & 6.0 & 6.0 & 2.0 & 4.0 & 7.0 & 6.0 \\
\hline 1 & 16 & 4.0 & 7.5 & 5.0 & 5.0 & 2.0 & 4.0 & 7.0 & 6.0 \\
\hline \multicolumn{2}{|c|}{$\operatorname{LSD} \alpha=006$} & 1.5 & 1.0 & 2.0 & 1.5 & 2.0 & 1.5 & 1.5 & 2.0 \\
\hline 6 & 2 & 9.0 & 9.0 & 9.0 & 9.0 & 7.0 & 8.0 & 8.0 & 8.0 \\
\hline 6 & 5 & 7.0 & 8.5 & 8.5 & 8.5 & 7.0 & 6.0 & 8.0 & 8.0 \\
\hline 6 & 7 & 5.0 & 8.0 & 8.0 & 8.0 & 5.0 & 6.0 & 7.5 & 7.5 \\
\hline 6 & 9 & 4.0 & 8.0 & 6.0 & 6.0 & 5.0 & .50 & 7.0 & 6.0 \\
\hline 6 & 12 & 2.0 & 7.0 & 5.0 & 5.0 & 3.0 & 4.0 & 5.0 & 4.0 \\
\hline \multicolumn{2}{|c|}{$\operatorname{LSD} \alpha=006$} & 2.0 & 1.5 & 1.5 & 2.0 & 1.5 & 2.0 & 2.0 & 2.5 \\
\hline 20 & 1 & 7.0 & 9.0 & 9.0 & 9.0 & 7.0 & 8.0 & 8.0 & 8.0 \\
\hline 20 & 2 & 6.0 & 8.0 & 8.0 & 8.0 & 6.0 & 7.5 & 8.0 & 8.0 \\
\hline 20 & 3 & 5.0 & 6.0 & 5.0 & 5.0 & 4.0 & 5.0 & 5.0 & 5.0 \\
\hline 20 & 4 & 3.0 & 5.0 & 4.0 & 4.0 & 2.0 & 2.0 & 2.0 & 2.0 \\
\hline \multicolumn{2}{|c|}{$\operatorname{LSD} \alpha=0,05$} & 1.5 & 1.5 & 2.0 & 1.5 & 1.5 & 1.0 & 1.0 & 2.0 \\
\hline 28 & 1 & 6.0 & 8.0 & 9.0 & 9.0 & 7.0 & 8.0 & 8.0 & 8.0 \\
\hline 28 & 2 & 4.0 & 6.0 & 6.0 & 6.0 & 5.0 & 7.0 & 8.0 & 8.0 \\
\hline 28 & 3 & 2.0 & 6.0 & 5.0 & 3.0 & 2.0 & 5.0 & 5.0 & 4.0 \\
\hline \multicolumn{2}{|c|}{$\operatorname{LSD} \alpha=006$} & 1.5 & 1.0 & 1.5 & 2.0 & 2.0 & 1.5 & 1.0 & 2.0 \\
\hline
\end{tabular}

Explanations: 1 - non-wrapped, 2 - wrapped in perforated PE film, 3 - wrapped in unperforated PE film, 4 - wrapped in stretch film, ns non- significant difference.

Rating scale for visual quality of lettuce according to K a d e $\mathrm{r}$ et al. (1973):

9 - excellent, essentially free from defects; 7 - good, minor defects; not objectionable; 5 - fair, slightly to moderately objectionable defects; lower limit of sale appeal; 3 - poor, excessive defects, limit of salability; 1 - extremely poor, not usable. 


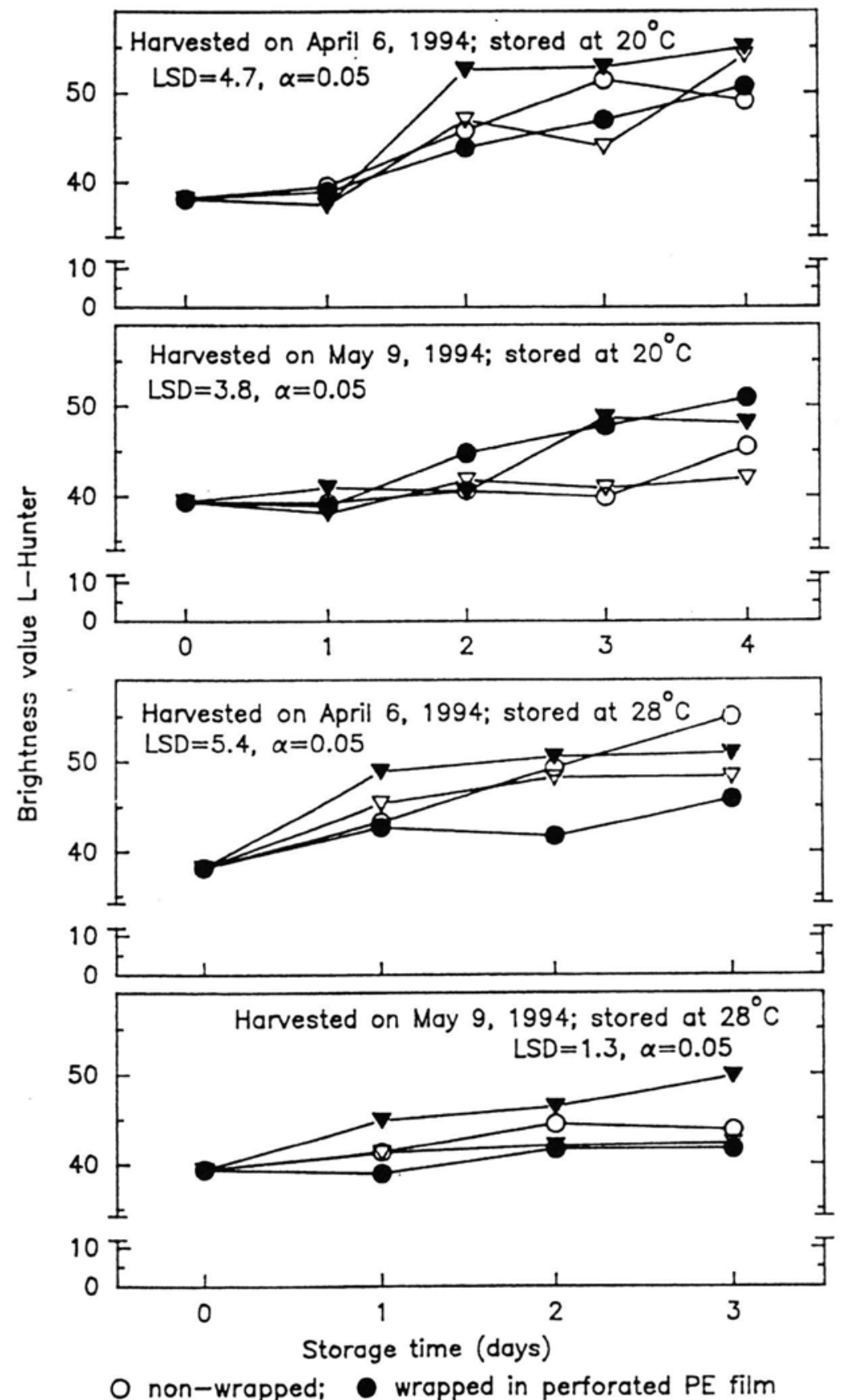

$\nabla$ wrapped in unperforated PE film; $\nabla$ wrapped in stretch film

Fig. 4. Changes of brightness value (L) of lettuce during storage at temperature 20 and $28^{\circ} \mathrm{C}$ 


\section{CONCLUSIONS}

1. Lettuce can be stored up to ten days at temperature $1^{\circ} \mathrm{C}$, and eight days at temperature $6^{\circ} \mathrm{C}$ without quality changes. After this time of storage changes of ascorbic acid and quality (colour and smell) were occurred.

2. The lettuce wrapped in unperforated PE film, and in stretch film lost much faster ascorbic acid than those non-wrapped and wrapped in perforated PE film.

3. The lettuce wrapped in perforated PE film and stored at $1{ }^{\circ} \mathrm{C}$ were best protected against loss of quality among investigated storage conditions.

The studies were supported by Grant No. 5S 30704606 obtained from Polish Committee for Scientific Research (KBN).

\section{REFERENCES}

A d a m i c k i F., 1989. Przechowywanie warzyw w kontrolowanej atmosferze. Biul. Warzyw. Suplement 1: $107-118$.

B o r o w s k i E., M i c h a ł e k W., 1994. Wplyw czasu i warunków przechowywania na zawartośc wybranych składników w liściach sałaty. Cz. I. Zmiany w zawartości wody, azotanów i azotynów. Annales Universitatis M. Curie- Skłodowska, II (5): 33-41.

B ö t t c h e r H., 1988. Qualitatsvernderungen wauhrend der Lagerung von Kopfsalat (Lactuca sativa L. var. capitata L.). - Mitt Ernahrungsphysiologische Qualitat. Nahrung 32 (1): 27-36.

He i m d a 1 H., K u h n B. F., Poll L., La rs e n L. M., 1995. Biochemical changes and sensory quality of shredded and MA packaged iceberg lettuce. J. Food Sci. 60 (6): 1265-1268.

K a d e r A. A., Li pto n W. J., M o r r i s L. L., 1973. Systems for scoring quality of harvested lettuce. Hort Science 25 (6): 408-409.

M a to e s M. K. D., C a n t w e 11 M., K a d e r A. A., 1993. Phenolic metabolism and ethanolic fermentation of intact and cut lettuce exposed to $\mathrm{CO}_{2}$ enriched atmospheres. Postharvest Biol. Technol. 3: $225-233$.

M c D o n a I d R. E., R i s s e A., B a r m or e Ch. R., 1990. Bagging chopped lettuce in selected permeability films. Hort Science 25 (6): 671-673.

P ouls e n N., J o h a n se n A. S., S ore n s e n J. N., 1995. Influence of growth conditions on the value of crisphead lettuce: Quality changes during storage. Plant Foods for Human Nutrition (Dortrecht) 47 (2): $157-162$.

R ożek S., Leja M., M y c zkowski J., M a re czek A., 1994. The effect of fertilization with different forms of nitrogen on greenhouse lettuce quality and its changes during storage. I. Content of certain nutritive compounds. Folia Horticulturae 6/1: 41-51.

R oże k S., Leja M., M y c z kow ski J., M a r e c z e k A., 1995. The effect of fertilization with nitrate and urea forms of nitrogen on quality and storage ability of lettuce grown in a foil tunnel.

I. Content of certain nutritive compounds. Folia Horticulturae 7/1: 91-105.

\section{Wpływ temperatury i rodzaju opakowania na jakość składowanej sałaty}

Streszczenie

Sałata odmiany Sanora bez opakowania oraz opakowana w perforowaną folię PE, litą folię PE i w folię rozciągliwą byla przechowywana w różnych temperaturach: $1,6,20$ i $28^{\circ} \mathrm{C}$. Stwierdzono, że sałata 
ta może być przechowywana w temperaturze $1^{\circ} \mathrm{C}$ do $10 \mathrm{dni}$, zaś w temperaturze $6^{\circ} \mathrm{C}$ do 8 dni. Dluższy czas przechowywania powodowal znaczące straty jej jakości. W czasie pierwszych 2-3 dni przechowywania w tych temperaturach nie obserwowano ubytków kwasu askorbinowego, suchej masy, barwy i wartości organoleptycznej. Szybsze ubytki kwasu askorbinowego stwierdzono podczas przechowywania sałaty opakowanej w folię litą PE oraz rozciągliwą w porównaniu do strat występujących podczas przechowania sałaty opakowanej w folię perforowaną PE. Spośród badanych kombinacji najlepsze zachowanie jakości sałaty głowiastej masłowej stwierdzono podczas przechowania w opakowaniu z perforowanej folii PE przy temperaturze $1^{\circ} \mathrm{C}$. 